\title{
Literatura Periférica: Challenging São Paulo’s Cultural Segregation
}

\author{
Leonora Souza Paula, Rice University, USA
}

\begin{abstract}
In this article, I discuss how the works produced by authors identified with the twenty-first-century literary movement known as Literatura Periférica respond to and intervene in São Paulo's excluding pattern of culture distribution. Having lived in the city's peripheries themselves, these authors have been writing about life on the margins and centering their works on traditionally excluded groups. This work discusses the ways in which Literatura Periférica renders visible a social vision of the world in which the periphery is understood and represented not as a stigmatized culturally impoverished space, but as a legitimate site of enunciation for representing local lived experiences. While recognizing the periphery as a legitimate site of cultural production, I demonstrate how the collaborative peripheral identity contributes to the construction of a new imaginary for the symbolic and material space occupied by the socially excluded and racialized peripheries.
\end{abstract}

Keywords: Periphery, Literature, Afro-Brazilian, Cultural Segregation, Peripheral Identity

\section{Urban Development and Cultural Segregation}

$\mathrm{T}$ The works produced by authors identified with the twenty-first century movement known as Literatura Periférica focus on themes pertaining to life in social-spatial periphery of Brazilian society. Having lived in these spaces themselves, these authors have been writing about life on the margins and centering their work on traditionally excluded groups. In general, these narratives focus predominantly on representations of the dire experiences of discrimination, inequality, and segregation associated with being poor in contemporary urban Brazil. In particular, Literatura Periférica reveals that even though not immediately associated with a cultural product typical of the peripheries the literature produced in that space is a legitimate form of cultural expression where Brazil's social realities and its representations are confronted. Beyond the production and publication of literary texts, other types of activities such as readings, workshops, and educational programs are also associated with Literatura Periférica. Such activities represent the strong sense of community and empowerment emerging in and from these territories. Besides promoting the recognition of the periphery as a site of cultural production, these works also function as a terrain for the

The International Journal of the Constructed Environment

Volume \#, Issue \#, 2015, www.constructedenvironment.com, ISSN 2154-8587

(丹 $\begin{array}{llllll}C & O & M & M & O & N \\ G & R & O & \cup & N & D\end{array}$

(C) Common Ground, Leonora Souza Paula, All Rights Reserved

Permissions: cg-support@commongroundpublishing.com 
empowerment of racial identity. This is due to the fact that the daily struggles of the peripheries' vast majority black and brown populations are represented in one way or another as tales of resistance and survival echoing a strong history of black resistance dating back to the quilombo, the free runaway slave communities of the colonial period. As a matter of fact, Literatura Periférica texts commonly represent the peripheries of Brazilian cities as a contemporary urban quilombo, thus directly linking historical sites of black resistance to contemporary urban sites of afro-descendant communities characterized by a strong sense of identity affirmation. Literatura Periférica, I argue, while not entirely integrated as a cultural product, effectively challenges historical patterns of cultural segregation through the articulation of a strong sense of affirmation based on the recognition of the legitimacy of the space from which they speak.

Considerably, a significant number of Brazil's Literatura Periférica production is concentrated in São Paulo, the country's largest city and home of its most densely inhabited peripheries. In the context of Brazilian cities, periferia (periphery) is used to identify vast areas of habitation and settlement outside the central zones of the city that have been historically occupied by low-income and non-white populations. Formed in the late 19th century, the first settlements were home to freed slaves and low-income workers with no land ownership, and with only meager job opportunities. In the early decades of the 20th century, while Brazil promoted massive European immigration to whiten the nation and to fulfill the demands of its incipient industrial development, São Paulo grew rapidly without a matched commensurate urban planning. By mid-century, rural migrants attracted by the city's wealth settled in the peripheries, self-building their houses mostly in irregular settlements. In the decades following up until late twentieth century, as the outskirts continuously grew without the adequate resources to support its expansion, São Paulo's peripheries became associated with neglected infrastructure, insecurity and criminality. It is estimated that currently two thirds of the city's population ( 8.4 million) live in precarious housing conditions. ${ }^{1}$ Today, São Paulo's vast peripheries surround an essentially large island of elegant apartment and office towers located at the city center.

Despite the steep social inequality evidenced in the spatial organization, São Paulo's accumulated wealth has secured its position as Brazil's most influential city. The city motto Non ducor duco - meaning I am not led, I lead - in use since 1917, epitomizes the city's adoption of a narrative of leadership which was first legitimized by its transformation from a coffee production town into Brazil's center of industrial production in less than fifty years. Subsequently, as the city concentrated the largest share of the country's industrial production and economic growth during the second half of the twentieth century, São Paulo had come to symbolize Brazilian modernity. However, the development of São Paulo as a modern city has followed a very disperse and exclusionary urban planning where the best resources and infrastructure were allocated to the center, while the outskirts received little to no development funds. Not surprisingly, the city's current cultural landscape mirrors the allocation of wealth where spaces dedicated to culture and education are concentrated in the center and virtually

\footnotetext{
${ }^{1}$ According to the 2010 National census.
} 
absent in the peripheries. That is not to say the city's outskirts lack cultural production, quite the contrary, the intense literary activity present in different communities demonstrates that beyond music and street art, other forms of cultural expression are also representative of that space. In rendering visible a vision of the world in which the periphery is understood and represented not as a stigmatized culturally impoverished space, but as a legitimate site of knowledge production, Literatura Periférica challenges the model of exclusionary modernity where almost all resources are concentrated in the wealthy center while the peripheries are overlooked.

\section{Literatura Periférica and the Culture of the Periphery}

While associated with the notion of socio-spatial periphery, the term Literatura Periferica, has its origins in a different context. In the 1970s, a literary movement known as Literatura Marginal emerged in different cities in Brazil. Produced and commercialized independently by poets voicing their dissent to the dictatorial regime that ruled Brazil from 1964 to1985, the movement followed a "do it yourself," defiant attitude toward the state of mainstream cultural production at that time characterized by heavy censorship and a compliant cultural industry. The term marginal used in association with that particular literary production "oscillated between a series of meanings: marginal to the canon, marginal to the editorial market, marginal to the political life of the country" (Hollanda 2014, 246). However, while positioning themselves as marginalized political and cultural actors, 1970s Literatura Marginal writers occupied a socially privileged position in that they were mostly white middle class intellectuals who were mainly invested in confronting the silence imposed by the military dictatorship.

The term Literatura Marginal was reclaimed in the early 2000s by writer Reginaldo Ferreira da Silva, known as Ferréz, who organized the publication of three special issues of the popular Caros Amigos magazine (2001, 2002, 2004) featuring collections of works produced by authors who later became associated with periphery literature. The special issues were titled: Literatura Marginal: A Cultura da Periferia I, II and III (Marginal Literature: The Culture of the Periphery). It is important to note that this new local literary production has been a part of periphery communities since the late 1990s and date back to before the organization and publication of the collections. A product of that context, the three issues of the special edition of Caros Amigos gathered forty-eight authors and eighty texts in a variety of genres ranging from short fiction, to manifestos, poetry, and rap lyrics. Significantly, near half of the published volumes were distributed free of charge in low-income schools, prisons, and local cultural events, and sold in newsstands in the peripheries (Reyes Arias 2013, 31). Widely read and circulated, the magazine's special editions made clear that the various manifestations of the culture of the periphery were not restricted to the production of music and urban art, the most recognized and authorized forms of cultural expression associated with that space. The works organized by Ferréz revealed to a larger audience that, even though not immediately recognized as a cultural product typical of the periphery, literature in its most diverse forms was as representative of that social-spatial reality as much as the other cultural genres. Not only that, the publication of that body of work asserted the black and poor periphery as a legitimate cultural producer of a genre traditionally located in the socio-economic-cultural center. With that in mind, 
my analysis favors the term Literatura Periférica rather than Literatura Marginal in an attempt to highlight the socio-spatial periphery as a locus as much as an ethos of enunciation. In other words, the decision to focus on the peripheral rather than the marginal aspect underlines the fact that periferia here functions not only a place of origin but also a frame of reference. Considering that the intersection between space and peripheral identity is simultaneously constructed on the text and on the ground (such as saraus and other events), it is fair to say that Literatura Periférica produces not only new narratives but also alternative ways of voicing social demands. That is, writing is the space where a process of reterritorialization of the periphery is made possible by the recreation of imaginaries, models, literacies, and understandings about what constitutes the periferia. In this process of writing new narratives, locally informed demands about social justice are articulated.

Relatively independent of the mainstream literary market, Literatura Periférica's distribution happens mainly via small presses, self-publishing, blogs, and in the numerous local spoken word type of literary gatherings known as saraus commonly led by and dedicated to periphery writers and held in bars and other local community spaces. Perhaps the most well known, the Cooperifa sarau, organized by poet Sérgio Vaz, has recently celebrated its $14^{\text {th }}$ anniversary. Held at Zé Batidão bar located in the Capão Redondo district, Cooperifa hosts weekly events where periphery writers share their own original poetry, short fiction, rap lyrics as well as read works by other authors. Politically and symbolically relevant to the community, these gatherings affirm the periphery as a dynamic cultural space via the recognition and practice of local agency. That is, besides producing their own works, Literatura Periférica writers create an autonomous form of cultural expression that is not bound by the legitimization of mainstream cultural industry. Therefore, by taking a relatively self-sufficient attitude, the culture of the periphery poses questions that challenge the stigmatization of the periphery while simultaneously proposing an alternative attitude toward the predominant Brazilian cultural industry. That is not to say that some of these works do not get absorbed by the mainstream literary market. Significantly, Ferréz and Sérgio Vaz have signed with larger publishing houses having achieved relative success in the traditional literary and cultural circuit. With that in mind, it is fair to say that Literatura Periférica occupies a liminal space where the empowering idea of self-sufficiency on one hand, and the model of the self-managed artist - in the mode of neoliberal creative economy - on the other, inadvertently contribute to the instrumentalization of precarity as a means of growing cultural markets. Rather than mutually exclusive, however, the relationship between the independent and the traditional literary market is regarded by periphery writers as an opportunity to further the goals of diversifying the debate about contemporary literature in Brazil, a model of cultural production that has historically excluded the marginalized as knowledge producers. Thus, more than caught in an irreconcilable predicament, periphery writers "exhibit various levels of reflective engagement with the commercial and political aspects of their work" and "tend not just to position themselves as critics but to use their work to explore the barriers" of effective criticism (Brouillette 2014, 17). To cite an example, after the sale success of his first novel, Capão Pecado (2000), Ferréz refused a proposal from a North American producer who offered to buy the novel's rights for a film adaptation on the grounds that a big budget film version of the 
text could reinforce negative stereotypes associated with Capão Redondo, the author's birthplace and main source of inspiration to the fictional narrative.

Despite cases of commercial success and visibility in mainstream culture, in order to take part in the culture of the periphery, one usually must travel the city's outskirts where the weekly saraus and other events take place. In any given week, one can find a variety of events ranging from hip-hop concerts, samba gatherings, theater performances, dozens of saraus, and regular hands-on workshops on documentary film making, music, and art, almost all taking place in the different peripheries of the São Paulo. ${ }^{2}$ The popularity of these events has resulted in the opening of some local cultural centers and of spaces for the events to travel to the city center where they are held in libraries, cultural centers, and universities. ${ }^{3}$

Significantly, the movement achieved national visibility at a time when political and social activist movements for the civil rights of afro-descendants in Brazil had finally succeeded in including their claims into the national agenda (1990s-2000s). By the 1990s, the hegemonic ideology of racial democracy was being broadly rejected as Brazil's active black movement denounced racism as a widespread practice. Several initiatives have since then been promoting the acknowledgment and inclusion of black and brown populations in the political, economic, and cultural domains of society. In 2001, several Brazilian higher education institutions established race-based affirmative action for the first time. As a result of its gradual implementation, in 2013 Brazil passed a federal law requiring its public universities to reserve half of their admission spots to public school students, low-income students, and afro and indigenous descendants. In 2003, the Lula administration passed a comprehensive law requiring schools to include Afro-Brazilian and African history and culture as part of their curriculum. In the same year the Special Office for the Promotion of Racial Equality (SEPPIR) was created to ensure that governmental policies were put in practice. Founded in 1988 under the Ministry of Culture, the Palmares Cultural Foundation was created to promote and preserve Afro-Brazilian cultural, social, and economic values. The São Paulo Feira Preta has, since 2001, been promoting entrepreneurship in the afro-descendant community in order to generate more inclusive opportunities of participation in the local and national economy.

Evident in this context is an effort to engage Brazilian society in meaningful debates about discrimination and inclusion on several domains of society, including the cultural one. The fact that Literatura Periférica emerged at the time is significant because like the aforementioned efforts, it has been promoting a positive attitude about black identity in Brazil while making public the literary production of blacks living in the peripheries of the cultural landscape. In addition, by contesting the normalcy of placing Afro-Brazilian populations in the geographic and symbolic periphery of culture, the movement effectively uses literature as a vehicle for calling attention to the historical debt Brazilian society has with its afro-descendant population.

\footnotetext{
${ }^{2}$ For weekly programs see: http://www.agendadaperiferia.org.br.

${ }^{3}$ One of the most important spaces, the Espaço Cultural Periferia no Centro (Periphery in the Center Cultural Space) is open weekly to promote and support the presence of periphery culture in the city center.
} 
However, even though they have been effectively participating in the national effort to shift and improve the conditions of life for black Brazilians, the Literatura Periférica project distinguishes itself for being an autonomous and self-reliant initiative, not resulting from a government led program. That is, while possibly benefiting from state programs, such as the several programs for social inclusion put forth by the Lula administration (2003-2011), as well as from state and municipal inclusive policies, periphery writers initially took the creation and promotion of culture into their own hands and only later developed partnerships with public and private sectors.

\section{São Paulo and Cultural Segregation}

The cultural landscape of São Paulo followed the city's exclusionary urban development, as mentioned earlier. The city's rapid growth in the 1950s was modeled after a pattern of polarized concentration in which "the center received improvements in infrastructure and the most obvious symbols of modernity: it was dominated by skyscrapers - increasingly of modernist design - that multiplied in a matter of a few years... In the periphery...the lack of any kind of state support, investment and planning generated a very different type of space" (Caldeira and Holston 2005, 150). As a consequence, the allocation of cultural spaces in the city has traditionally favored areas already endowed with infrastructure, services, and access to mobility. Currently, most of São Paulo's libraries, cultural centers, parks, museums, cinemas, and theaters are located in areas

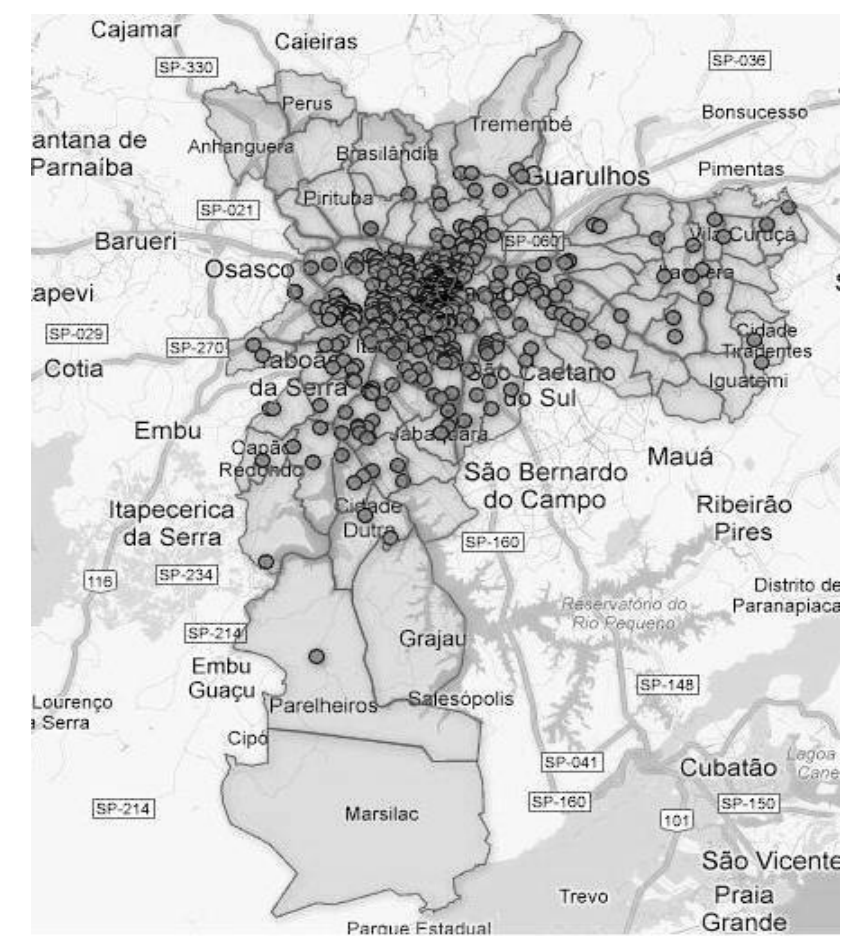


well served with convenient public transportation and other private and public services (Figure 1).

Figure 1: Cultural Centers in São Paulo

It goes without saying that despite the unequal distribution of resources, culture has been produced in the peripheries of Brazilian cities since its formation albeit with very little recognition for its cultural value, being commonly labeled as poor taste, "mass culture," and lacking in quality and therefore not deserving of recognition as culture. While still facing a similar disdainful attitude, periphery artists have, before and in spite of wider acceptance, singlehandedly created a relatively independent productive environment that does not rely on legitimization from the center in order to exist and thrive. Even though periphery cultural production such as graffiti art and hip-hop have been incorporated into the city's cultural agenda since the 1990s, that relative inclusion has always been marked by a marginal condition. An illustrative example is the differentiated treatment hip-hop artists have received from various São Paulo administrations in regards to the city's principal cultural agenda, such as the widely popular event Virada Cultural. Created during the administration of Mayor José Serra (20042006), Virada Cultural combines a series of music shows, theater, and art exhibitions that take place in dozens of sites, in a period of twenty-four hours, chiefly downtown, following the model of Paris Nuit Blanche. In place since 2005, this entertainment-oriented event explicitly aims at attracting a middle class audience to occupy the city center while the preparation of the central areas as a stage for cultural consumption is accompanied by social cleansing in the form of the physical removal of local street populations. Despite Virada Cultural's discourse of multicultural approach and attention to diversity, evident in the management's publicized selection of artists, the event's spatial distribution reveals the city's historically problematic attitude towards its peripheries. The sites assigned to hip-hop performances in the 2008 edition, for instance, were conveniently situated in the neglected area of Parque Dom Pedro, a deteriorated and far off area isolated from the activities happening in the more central sites. In addition, the area was surrounded with a higher than usual deployment of police force, which engaged in random searches of "suspected individuals." Evident in the episode is the fact that cultural productions associated with low-income and mostly black and brown populations were placed in the geographic and symbolic periphery of culture within the very city center. In other words, the hiphop event was regulated by the allocation of undesired territories to unwanted groups while the prime areas hosted activities commonly associated with the white middle-class, such as classical music concerts, museum exhibitions, and drama performances. Not only that, by isolating the periphery in the very center of the city, the event became an opportunity for state control and surveillance, made clear with the considerably larger allocation of security forces, including a checkpoint, into the hip-hop site. Not surprisingly, "the urban geography of Brazilian metropolitan cities" argues Jaime Amparo Alves, has been "forged in racialized narratives of violence," such as the narrative of suspicion, made clear in the city's management of the music event (Alves 2010, 301). Such discriminatory practice against a cultural manifestation associated 
with black and poor periferia clearly establishes a boundary, which underlines marginalization and criminalization as conditions of inclusion into the terrain of culture.

While considered a more admissible and less threatening manifestation-no checkpoints have yet been deployed at saraus - Literatura Periférica, as an integral part of the culture of the periphery, also occupies a similar marginal space in the city's official agenda. Having said that, the fact that the common recognition of literature as a distinguished cultural expression grants Literatura Periférica a certain degree of acceptance that is not reserved for other forms of periphery culture as seen in the Virada Cultural example. To be sure, what renders this form of expression relatively more acceptable is not it's peripheral quality, but its status as literature. In light of that, it is no coincidence that the first works of Literatura Periférica to be integrated into the broader literary circuit were two novels: Cidade de Deus (1997) by Paulo Lins and Capão Pecado (2000) by Ferréz. While a variety of genres had been produced before these novels were published, they served as gateway agents so to speak, paving the way to the unveiling of a wider range of peripheral production perhaps due to the fact that as the most popular literary genre, the novel has consistently been used as legitimizing agent in the process of inclusion into what is considered canonical Brazilian culture. Yet, in defiance of the novel's status as a tool traditionally used in consolidating a (segregating) national identity project, the works by Lins and Ferréz have contributed to a new literary endeavor that has been "pushing back the frontier of literary possibilities in Brazil" (Schwarz 2012, 104) as they give literary form to a pervasive sense of social conflict from the perspective of those left outside.

Also relevant in understanding the emergence of Literatura Periférica is the fact that in a late twentieth century context of increasing inequality and segregation, narratives about experiences of violence and fear of violence, in the guise of a "talk of crime," have proliferated as crime became a "disorganizing experience and an organizing symbol" that is active in everyday life (Caldeira 2000, 19). More often than not, these crime narratives have relied on stereotypical representations of accounts of violence engrossing a discourse that records life in the periphery as a continuous sequence of criminal activity and violent death. These narratives of crime and violence are characterized by "old patterns of the criminal-pathological cataloguing of places and human types, the fear of social heterogeneity, the criminalization of social divisions, and the reinforcement of a kind of urban paranoia"(Süssekind 2002, 2). At odds with such oversimplified discourse, Literatura Periférica renders visible a different frame of reference regarding Brazil's most impoverished urban spaces and interrogates to what extent such narrative model effectively engages with Brazil's current social and cultural realities. It does so not by depicting the periphery solely as a space ridden by violence, misery and neglect, but by recognizing the various creative responses to structural discrimination produced in and from the point of view of the periphery. That is, the life of the community and its members in all its complexity, rather than their death and defeat, are the matter of Literatura Periferica works. More exactly, in lieu of making reference to the kind of violence that reasserts the dominant discourse of the "talk of crime" permeating the urban imaginary in contemporary Brazilian society, Literatura Periférica produces a new literary imaginary that overrides the image of the illiterate periphery resident and presents an image of the black and poor periphery as a legitimate cultural producer. To be sure, 
periphery writers do recognize violence as a constituting factor of the periphery as well as of the resident's lived experiences, but that kind of violence is seen neither a totalizing nor an inherent condition. Thus, rather than merely reproducing accounts of violence, criminal activity and violent death, the writers are concerned with narrating periphery life as an experience that although embroiled in crime and violence is not defined by it. Ultimately, the widespread presence of violence appears in Literatura Periferica works as a condition that can be altered and literature serves as one of the means of transformation. Therefore, within this new literary imaginary, periphery characters are the protagonists of their own stories who rely on their own agency and defy the naturalized representation of periphery men and women as victims or perpetrators. Other than conventionally portrayed as housemaids, inmates, servants, and drug dealers, periphery characters now also appear as students, educators, community organizers and writers. This is especially relevant in the context of the contemporary Brazilian novel which tends to favor the representation of privileged spaces and whose main characters are mostly white, middle class and male, while white women usually appear as housewives, black women as domestic workers or prostitutes, and black men almost uniquely as criminals. That comes hardly as a surprise if we consider the fact that in the literary production of contemporary Brazil, 72.7 percent of the published authors are men, of which 93.9 percent are white (Dalcastagnè 2012, 8). ${ }^{4}$

The shift in perspective brought forward by Literatura Periférica poses questions that challenge the stigmatization of the periphery while simultaneously proposing an alternative attitude toward a predominant discursive mechanism designed to reproduce ideas and attitudes about social, racial, gendered, and cultural inequalities. Therefore, beyond being a discursive register of a crime-ridden urban experience and aside from reproducing stereotypes about periphery residents, Literatura Periférica has emerged from and given rise to a particular ethos which offers a powerful critique of naturalized discourses of violence and victimization while articulating alternative ways of depicting life in the peripheries, thus challenging São Paulo practices of cultural segregation. Surely periphery cultural productions have existed prior to the commercial success of Paulo Lins and Ferréz and will continue to exist in different formats and it is precisely in this prolific productivity that strategies for a larger project of inclusion are found. Whether in longer fictional and non-fictional accounts or in poetry and short fiction, Literatura Periférica has become, together with other peripheral productions, a new player in the cultural landscape of urban Brazil.

\section{Collective Identity and the Periphery}

In order to understand how the culture of the periphery destabilizes the white privileged male cultural terrain is important to consider the concept of peripheral identity. Such identity is informed by an acute understanding of territory as more than simply delimitated space. Certainly, geographical isolation is a fundamental part of the social construction of the space of the periphery, but that isolation also enables the constitution of networks of collaboration based upon

\footnotetext{
${ }^{4}$ The numbers were found in study involving 165 authors published by the three best selling publishing houses between 1990 and 2004. For more see Dalcastagnè 2012.
} 
a very specific local identity. In fact, it is by mobilizing culture as the grounds for the articulation of this spatial identity that periphery writers bring into play a certain understanding of the category of the cultural as a way to reflect on how to "make violent and unequal orders meaningful to people, to secure their resignation or compliance, and to defend alternative and resistant ways of being" (Pratt 1998, 435). That is to say, the category of the cultural intersected with that of space becomes a crucial site for understanding not only how geographical and social isolation is constructed, but also how alternative forms of identity come forth. A third element intersecting with culture and space, the conspicuous afro-descendant racial makeup of the periphery is a fundamental element in the constitution of the peripheral identity. This is not only due to an overwhelming afro-descendant presence but also to the common experiences of discrimination associated with being black in contemporary Brazil. Consequently, the collective awareness of the existence of institutionalized racial discrimination and of hostile attitudes that result from that structure, assumes a critical stance toward their position in relation to the rest of society. Beyond voicing a critical attitude toward structural forms of racial discrimination, black and brown writers living in the periphery articulate a strong sense of affirmation of the legitimacy of the space from which they speak. It is this strong sense of a culturally, spatially and racially informed identity that Literatura Periférica embodies and enunciates.

A fundamental aspect of Literatura Periférica's project, peripheral identity contests the normalcy of placing Afro-Brazilian populations in the geographic and symbolic periphery of culture by making use of literature as a vehicle for calling attention to the ways in which the recognition of shared experiences of discrimination generate a sense of collectivity and collaboration. The emphasis on the collective experience as opposed to the individual one is the main marker of Literatura Periférica. While recognizing the importance of individual precursors of periphery literary, such as Carolina Maria de Jesus' bestseller diaries Quarto de Despejo (Child of the Dark, 1960), Literatura Periférica writers turn to collaborative practices to assert their position in the cultural landscape. In the case of Carolina Maria de Jesus, a black woman living in the Canindé favela located in the periphery of São Paulo during the 1960s and who raised her three children on her own barely making a living by gathering and selling scraps to local shop owners, the notion of collective identity was not necessarily a positive one. The diaries title, Quarto de Despejo or junk room makes reference not only to the miserable state of her material conditions but emphasizes the place occupied by the Canindé favela and its inhabitants in relation to the city and to society. That is, in Carolina's work, the periphery is regarded not only as a place of abject misery due to the complete lack of basic infrastructure, but also as a place where the historically black and poor human surplus of Brazilian society is disposed of. Carolina repetitively equated Canindé specifically, and the periphery in general, to the senzala (slave shack), always reminding the reader of the expendability of the black poor body. Therefore in her diaries, being associated with the periphery necessarily meant being regarded as less than human. Constantly ashamed of her condition, Carolina sought to leave the periphery and saw in her writing the only ticket out of misery. With only a second grade education, writing was to her a form of medi(t)ation between her bleak daily experiences and the possibility of escaping those conditions. It is important to note that even though Carolina's position was that of a critical intervention in racially and socially discriminating discourses, "she did not project 
herself politically as the voice of the oppressed but, rather, she denounced her living conditions and expressed her adamant will to be free of the bondage of scarcity" (Jaguaribe 2004, 333). Therefore, rather than projecting herself as the spokesperson for poor blacks, Carolina's desire was to distance herself from others like her and from the periphery. Regarded as a curiosity, Carolina's diaries were capitalized on by her editor Audálio Dantas and soon lost their popular appeal. Even though her fierce criticism to gender, racial and social discrimination in Brazil resonated with the readers, the fact that she refused to identify herself with other periphery residents rendered her voice an easy target to exoticizing readings and representations. Only recently Quarto de Despejo has been getting the due recognition as one of the most important works in twentieth-century Brazilian literature. ${ }^{5}$

The significant shift from individual to collective voice carried out by twenty-first century Literatura Periférica reflects how notions of community and territoriality are seen as integral parts of the peripheral identity. Evidence of that is the fact that almost four decades after the publication of Quarto de Despejo, Literatura Periférica revisited the representation of the periphery and questioned its naturalized association with senzala images. Even though references to senzala have not been entirely abandoned, the periphery has been often represented as a new configuration of runaway slaves quilombo communities. In evoking an image of collective black resistance as opposed to chronic abuse and oppression, Literatura Periférica speaks to the recognition of the periphery as a space where the sense of identity is informed by an attitude of affirmation. Furthermore, the representation of the quilombo as a symbol of black resistance, community, and territoriality serves as a source of inspiration with enough galvanizing power to influence how communities in the peripheries see and represent themselves. Ferréz' own process of identification with two historical figures known as community leaders alludes to sense of identity that is informed by an attitude of defiance. One of the most visible figures in Literatura Periférica, Reginaldo Ferreira da Silva's pen name Ferréz combines the first syllable of Ferreira, the last name of Lampião, the revered cangaceiro (bandit) active in Brazil's backlands in the 1930s, and the first letter of Zumbi, the mythical leader of Palmares (1605-1694), Brazil's largest quilombo. In assuming such name, Ferréz sends a clear message about his sources of identity formation while simultaneously being himself a source of identity formation and affirmation for the community. Clear in Ferréz's attitude is the assertion that writing is one of the spaces where contemporary collective struggles for affirmation are waged and that the periphery is the modern day quilombo where resistance, as opposed to chronic abuse and oppression, is engendered.

Another example appears in the language and attitude of cooperation used in the processes of self-definition of literary and cultural collectives. Before becoming the well-known sarau, Cooperifa - a neologism formed after the combination of the words cooperação (cooperation)

\footnotetext{
${ }^{5}$ Author of several books, Carolina Maria de Jesus has rarely been given full consideration as a writer until this day. In fact, rather than setting her literary career in motion, the success of her diaries limited the perception editors and audience had of Carolina, confining her to the realm of the one hit wonder.
} 
and periferia - was a collective of periphery artists that got together to create multi-cultural events in an abandoned factory in São Paulo's southern municipality of Taboão da Serra. The idea behind Cooperifa was to create space for a type of culture that was identified with and represented the peripheries (Vaz 2008, 75). Happening since the early 2000s, the events were possible because the artists themselves worked in a co-op manner where all presenting artists put in labor towards the organization and no one got any profit out of it. The relative success of the events was the result of diverse programing, free admission, but mostly a sense of collectivity that prompted the group to come together in the first place. Nowadays, Cooperifa organizes not only the sarau but it is also responsible for the Mostra Cultural Cooperifa (Cooperifa Cultural Fair), a nine-day-long event that takes place in periphery public schools, bars, local cultural centers and public spaces such as rooftops used to project films. Coordinated by local residents, the series of events intends to attract a local audience and showcases local artists along with nationally recognized artists (Figure 2).

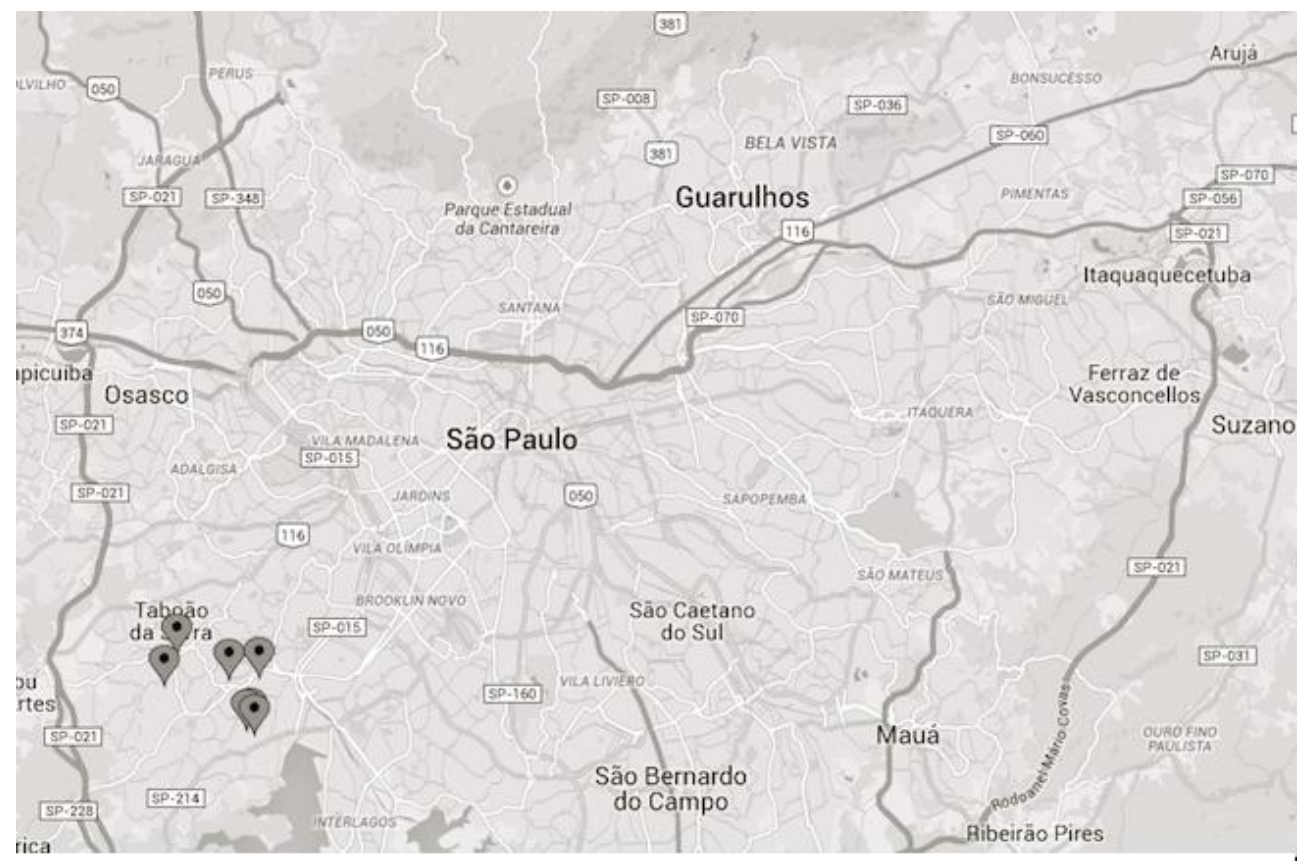

Figure 2: Cooperifa Cultural Fair Locations

In this sense, periphery culture serves as the terrain upon which a collective experience of participation is built. This is most noticeable in the literary gatherings known as saraus. As already mentioned, these events are dedicated to periphery writers and are usually held in bars located in the city's peripheries. Taking place in all regions of São Paulo, saraus regularly congregate dozens and sometimes hundreds of people and have been helping to change the 
cultural dynamics in the city, as well as the representations about the periphery. In place since the late 1990s, saraus have a very specific social function, namely the occupation and transformation of local public sites into cultural spaces. The aforementioned Cooperifa sarau, traditionally takes place every Wednesday night at a neighborhood bar in the Capão Redondo community in São Paulo's southern zone, and welcomes dozens of writers who go on stage to share their poems, prose, spoken word with an always enthusiastic audience.

Needless to say, in the absence of a significant number of libraries, culture and art centers, these local bars have been, since the periphery's early days, some the very few spaces for community engagement; a space where members can come together to socialize and share their experiences. Rather than mere coincidence, the cultural deserts that characterize Brazilian's urban peripheries are a result of poor urban management and a total disregard for the most basic needs of the community such as infrastructure, reliable public transport, health clinics, and spaces for leisure. In that context, the space occupied by the saraus makes a critical statement that challenges the total absence of state sponsored cultural spaces. In addition, as spaces that foster and enable critical positions by raising awareness about racial and social discrimination, the literary gatherings work as forums where individual experiences with racism and social injustice, rather than viewed as an isolated phenomenon, are represented as structural. For these reasons, the collective and collaborative experience of the sarau as an expression of peripheral identity functions as a mechanism for the contestation of São Paulo's concentration of culture in the wealthy center.

This sense of collectivity is also noted in the instances when the culture of the periphery travels to the center. In the past years, there have been hundreds of events in which periphery writers and artists are invited to present their work in spaces located in the spatial and symbolic center of the city. In these events, literary collectives from different peripheries of São Paulo are invited to read their works in cultural spaces in the city center. In most cases, the writers reading at the events are part of collectives such as the Sarau Elo da Corrente, Sarau do Binho, Slam da Guilhermina, Cooperifa, among others. Notably, as they read from their own works, these writers unmistakably enunciate a collective voice. Invariably, the authors self identify as being the resident of a certain periphery, which carries with itself the notion of belonging to a specific geographical, social, and racial location. The peripheral collective identity expressed by these writers makes clear that periferia is not just a location on the map, but a source of identity, a set of ideas and shared experiences in a context of discursive and material segregation.

\section{Final Remarks}

Part of a larger movement emerging in the peripheries of Brazilian cities, Literatura Periférica brings to the table valuable tools in the struggle against cultural segregation. Characterized by an attitude of defiance and self-determination Literatura Periférica cuts across the boundaries established by dominant culture, which concentrates knowledge production in the socio-spatial center of the city. In La Ciudad Letrada, Ángel Rama underscores how preconceived notions of ideal cities pay little attention to the specificities of the land upon where they are built or to the practices of those who live there. Perhaps more importantly, he argues that the (intellectual) elite, 
allied with dominant economic interests have, since the foundation of the first Latin American cities, promoted that same ideal urban model as a means to legitimize unequal power relations. As a response to that model still present in Brazilian cities today, São Paulo's Literatura Periférica effectively mobilizes culture as a space in which such segregating model is challenged and a new imaginary for the representation of racialized marginality is activated.

\section{REFERENCES}

Amparo Alves, Jaime. 2010. "Narratives of Violence: The White Imagination and the Making of Black Masculinity in City of God." Sociedade e Cultura 12 (2): 301-18.

Brouillette, Sarah. 2014. Literature and the Creative Economy. Stanford: Stanford University Press.

Caldeira, Teresa Pires do Rio. 2000. City of Walls: Crime, Segregation, and Citizenship in São Paulo. Berkeley: University of California Press.

Caldeira, Teresa Pires do Rio, and James Holston. 2005. "State and Urban Space in Brazil: From Modernist Planning to Democratic Interventions." Managing Urban Futures: Sustainability and Urban Growth in Developing Countries. Burlington, VT: Ashgate.

Caros Amigos. 2001. Literatura Marginal: A Cultura da Periferia: Ato I. São Paulo, SP. Editora Casa Amarela.

2002. Literatura Marginal: A Cultura da Periferia: Ato II. São Paulo, SP. Editora Casa Amarela.

2004. Literatura Marginal: A Cultura da Periferia: Ato III. São Paulo, SP. Editora Casa Amarela.

Dalcastagnè, Regina. 2012. Literatura Brasileira Contemporânea: Um Território Contestado. Rio de Janeiro: EdUERJ.

Ferréz. 2000. Capão Pecado. São Paulo: Labortexto Editorial.

Hollanda, Heloísa Buarque de. 2008. "A Short Sketch on Some Signs of Transformation in the Brazilian Urban Imaginary." Brazil and the Americas: Convergences and Perspectives. Madrid, Iberoamericana.

2000. “Two Poetics, Two Moments.” Portuguese Literary \& Cultural Studies 4: 24554.

Jaguaribe, Beatriz. 2004. "Favelas and the Aesthetics of Realism: Representations in Film and Literature." Journal of Latin American Cultural Studies 13 (3): 327-42.

Jesus, Carolina Maria de. 1960. Quarto de Despejo: Diário de uma Favelada. São Paulo: Livraria F. Alves.

Lins, Paulo. 2002. Cidade de Deus. São Paulo: Cia das Letras.

Pratt, Mary L. 1998. "Where To? What Next?" Cultures of Politics/Politics of Cultures: ReVisioning Latin American Social Movements. Boulder, CO: Westview Press.

Rama, Angel. 1984. La Ciudad Letrada. Hanover, NH: Ediciones del Norte.

Reyes Arias, Alejandro. 2013. Vozes dos Porões: A Literatura Periférica/Marginal do Brasil. Rio de Janeiro: Aeroplano Editora.

Schwarz, Roberto. 2012. "City of God." In Two Girls: And Other Essays. London; New York: Verso.

Süssekind, Flora. 2002. "Deterritorialization and Literary Form: Brazilian Contemporary Literature and Urban Experience." Oxford: Centre for Brazilian Studies, University of Oxford. 
Vaz, Sérgio. 2008. Cooperifa: Antropofagia Periférica. Rio de Janeiro: Aeroplano Editora. 2011. Literatura, Pão e Poesia: Histórias de um Povo Lindo e Inteligente. São Paulo: Global Editora.

\section{ABOUT THE AUTHOR}

Leonora Souza Paula, Ph.D.: Assistant Professor, Department of Spanish and Portuguese, Rice University, Houston, Texas, USA 